\title{
Globalization, Internationalization, and the Recruitment of International Students in Higher Education, and in the Ontario Colleges of Applied Arts and Technology
}

\section{GEOFFREY CUDMORE}

Loyalist College

\section{ABSTRACT}

This paper explores general issues relating to globalization and higher education; the internationalization of higher education, and particularly the recruitment of international students. This subject is examined through a range of topics around the global development of the market approach to the recruitment of international students and a focus on the current situation regarding the recruitment of international students in the Colleges of Applied Arts and Technology in Ontario (CAATs). As the number of international students seeking educational opportunities grows to 7 million over the next 20 years, the ability of the CAATs, the Canadian educational system, and the governments of Ontario and Canada to market the welcoming and safe multicultural Canadian experience, and the excellence of the educational offerings and opportunities in CAATs to potential international students will, in great measure, determine their success and their survival in an increasingly globalized world. 


\section{RÉSUMÉ}

Cet article traite des questions d'ordre général que soulèvent la mondialisation et l'enseignement supérieur; l'internationalisation de l'enseignement supérieur et, en particulier, le recrutement d'étudiants étrangers. On y examine divers sujets liés à l'élaboration, à l'échelle mondiale, d'une stratégie efficace à adopter pour attirer ceux-ci en s'attardant principalement sur le recrutement des étudiants étrangers tel qu'il se pratique actuellement dans les Collèges des arts appliqués et de technologie de l'Ontario (CAAT). Étant donné que le nombre des étudiants étrangers qui veulent poursuivre leurs études au Canada devrait atteindre sept millions d'ici vingt ans, la capacité des CAAT, du système canadien d'enseignement et des gouvernements de l'Ontario et du Canada de faire valoir leur expérience multiculturelle ouverte et sûre, ainsi que l'excellence de l'enseignement et des possibilités qu'offrent les CAAT à d'éventuels étudiants étrangers, déterminera en grande partie leur succès et leur survie dans un monde de plus en plus globalisé.

\section{INTRODUCTION}

The Ontario Colleges of Applied Arts and Technology (CAATs) were established in 1967 to provide education and training directed toward the economic development of the province of Ontario. While the system's original mandate made no mention of any international activity on the part of the colleges, in 2002 the mandate of the CAATs was re-written to reflect the new provincial and global realities resulting from the rise of globalization. The mandate of the CAATs now challenges these institutions not only to provide accessible, quality, career education and training to enhance social and economic development throughout Ontario, but also to meet local, regional, and global marketplace demand (Ontario Ministry of Training, Colleges, and Universities, 2002).

This addition of the global marketplace reflects the CAATs ongoing need to respond to an increasingly multicultural society and the growth 
of the global economy and global inter-dependence. The CAATs recognized that students and programs needed to meet the demands of an increasingly global marketplace and have been developing programs and services to meet these challenges over the past two decades. Like those in most parts of the world (O'Banion, 1986; Hurabielle, 1998; Raby, 2000; Galway, 2000; Zeszolarski, 2001), the CAATs have undertaken a process of internationalization which has included the recruitment of international students, the internationalization of curriculum, links between international education and business interests, foreign language study, overseas academic programs, faculty exchanges, and technical assistance to other countries.

This paper explores general issues relating to globalization and higher education, and examines the current situation regarding the recruitment of international students in the CAATs as one of the most prominent manifestations of the internationalization of the Ontario colleges.

\section{Globalization and Higher Education}

Ostry (1999, p. 1) describes globalization, as “an ongoing process of deeper integration" among countries that has proceeded in stages since the end of World War II. She traces the roots of globalization from the early postwar decades with the focus on reducing border barriers to trade, to the 1970 s and 1980s when the liberalization of the movement of capital and the deregulation of financial markets began the process of global integration. Globalization further developed during the 1990s with the revolution in the development of Information and Communication Technologies (ICT), which made it cheaper and easier to develop and manage global production networks and led to the prominence of multinational enterprise as the "main funnel for the three engines of growth: trade, capital and technology" (Ibid., p. 2). The final integration flowing from the ICT revolution is the growth in electronic commerce, global telecommunications, and the new world of cyberspace, which, she notes, could eliminate national borders to the extent that "the term 'domestic policy' could become an oxymoron" (Ibid., p. 2). 
So what does globalization have to do with higher education, and why should the CAATs be concerned with internationalization and the global marketplace? A background paper, Canadian Higher Education and the GATS (AUCC, 2001), a brief to the House of Lords in the United Kingdom (Rikowski, 2002), and analyses by Stromquist (2002) make it clear that globalization and higher education relate in very specific ways. The World Trade Organization (WTO) promotes globalization by opening up all areas of social life, including the public services like education to international capital. The key WTO agreement for this purpose is the General Agreement on Trade and Services (GATS). Global trade in services currently amounts to approximately USD $\$ 2.2$ trillion, or a third of the value of total trade (AUCC, 2001). The GATS is a legally enforceable, multilateral agreement governing international trade in services such as construction, distribution, entertainment, telecommunications, tourism, and transportation. It also includes services which, in many countries (like Canada), have traditionally been in the purview of the public sector, namely education and health care. Rikowski (2001) characterizes the WTO's education agenda as the facilitation of the business takeover of education through its commercialization, privatization, and capitalization.

Although the AUCC brief comes to the conclusion that Canadian providers of education and training do not appear to be unduly hindered by barriers to trade in educational services, it found that barriers exist for a number of education providers in countries more active in education exports, such as the United States, the United Kingdom, and Australia. The barriers seem to be especially prevalent when it comes to establishing facilities abroad and less so in restricting the flow of international students (AUCC, 2001). How the GATS ultimately impacts higher education in Canada remains to be seen, while the expectation that it will have an impact is almost a certainty (AUCC, 2001).

Another impact of globalization on higher education is in the reductions in funding from various levels of government that have plagued the CAATs for more than a decade. This took hold at the federal level between 1984 and 1993, (Fisher \& Rubenson, 1998) and continued in Ontario under the 
Conservative governments between 1995 and 2003. These administrations had a general suspicion of public institutions, an emphasis on shrinking the welfare state, and a belief in the greater efficiency of the free market. In this sense, Canada was not alone. Currie and Newson (1998) found similar responses in their examination of the impact of globalization in Australia, Canada, Great Britain, and the United States. Dudley echoed this view in her review of globalization and educational policy in Australia.

The claim of globalization is that national economies are being increasingly subsumed into a global economy and that the discipline of international markets and money markets, rather than national, social, and/or political priorities, should determine public policy. These policies, almost without exception, require states to reduce public spending, deregulate capital and labour markets, minimize welfare provision, and either eliminate or privatize as much as possible of the welfare state. (Dudley, 1998, p. 25)

Altbach and Davis (1999) observed that current approaches to higher education funding emphasized the need for users to pay the cost of instruction, as policymakers increasingly viewed higher education as something that benefited the individual, rather than as a public good where benefits accrued to society. Stromquist (2002) explored the rationale put forward by international financial institutions like the World Bank, which he says support user fees on the principle of social equity. These leading proponents of globalization argue that the low or nonexistent tuition levels offered by many governments through their public universities and colleges, in fact, constitute a state subsidy to the rich, because many of the students who attend public universities belong to the middle and upper classes of society.

Knight (1997) describes globalization in higher education as the process whereby a college integrates an international dimension into the teaching/ training, research, and service functions. As institutions seek to deal with the impact of globalization and embark on the internationalization of their campuses, the recruitment of international students and the associated financial benefit has increased in importance. In Canada, foreign student 
enrolment in Canadian institutions currently represents the majority of exports of educational services (AUCC, 2001). Statistics Canada data show that in 1998-99 there were a total of 35,556 international students at the postsecondary level in Canada. In 1996, the Department of Foreign Affairs and International Trade (DFAIT) reported that international students contributed approximately $\$ 2.7$ billion to the Canadian economy. By 2000 , this had increased to $\$ 3.5$ billion (AUCC, 2002).

\section{Internationalization of Higher Education}

The importance of this discussion is illustrated in a recent study by Bohm, Davis, Meares, and Pearce (2002) that sets out the size of the global challenge for institutions over the next quarter century. The authors estimated that in 2000 , there were 1.8 million international students enrolled in institutions of higher education around the world, and projected that this global demand for international higher education will exceed 7 million places by 2025 . It was of particular interest that the authors also predicted that more than two-thirds of the global demand for international higher education would derive from Asia.

Hamrick (1999) offers the view that internationalization in higher education has been described in at least four ways. The "traditional" view of internationalization includes the academic activities one could find under a catalogue heading of International Studies. These include a variety of interdisciplinary programs in languages, political science, cultural anthropology, and sociology, which have as their goal the development of knowledge about other nations and cultures, and the ability to function well in the languages and customs of those cultures. Zeszotarski (2001) refers to this as the development of "intercultural adaptability," or the ability not only to apply one's knowledge of a foreign language, but to have the ability to adapt to the unspoken cultural context.

A second view of internationalization includes the range of activities that facilitate the interaction of domestic students with students and faculty from other nations to build a sense of global community. Hamrick includes such activities as study abroad and the recruitment of international students 
and faculty. Blair, Phinney, \& Phillippe (2001) found that American colleges were increasingly recruiting international students as a way to bring greater diversity to campuses and their surrounding communities. This view was supported in a brief prepared by the Association of Universities and Colleges of Canada (AUCC, 2002) which was submitted to the House of Commons Standing Committee on Citizenship and Immigration Canada. The authors make the case that international students are vitally important to Canada's future in that they bring a crucial global perspective to Canadian campuses. The brief also outlines the ways in which international students contribute significant economic benefits to Canadian universities and local communities across the country, and expand the definition to explore one aspect of the development of global community, the way in which over the long-term, foreign students become ambassadors for Canadian trade and political interests abroad. Galway (2000) describes this definition as the process of building greater understanding between cultures and nations, which could be driven by a philosophic approach and an orientation that sees international education as having a final goal of world peace and cooperation.

The third view is international education as foreign aid or technical assistance to other (primarily developing) countries. These would include activities such as faculty going overseas to teach foreign nationals, or specialized training programs (at home or abroad) with a focus on the learning of particular information or skills. Hurabielle (1998), in looking at the development of international education in Canada, found that in the early years, the majority of Canadian international education was rooted in liberal humanism and driven by humanitarian concern. He noted that at that time, the Canadian International Development Agency (CIDA) funded the projects, which were not expected to bring sizable financial returns. He further noted that many of the international students were technical or vocational educators who came to Canada for specialized teacher training in their discipline area.

The fourth view on internationalization is the preparation of people to function in an increasingly international and culturally diverse environment. 
This is much the same as the view of internationalized education as being a vehicle for the preparation of students for an "interdependent world" described by Galway (2000) and O'Banion (1992). This view includes many aspects of the international studies approach, but it also implies the infusion of international and cross-cultural information throughout the curriculum. Knight (1994) expands on this definition by introducing the notion that this is the practical, "market oriented" view of international education that strives to prepare students and countries to compete in the global marketplace.

Currie (1998) offers the view that it is necessary to differentiate between globalization and internationalization. She presents the example that universities have always been international in their recruitment of staff and students and in their curriculum. However, she asserts that a distinction should be made between the traditional sense in which universities have been viewed as global institutions and the globalization of university practices taking place today as part and parcel of their alignment within the marketplace.

This suggests that the literature provides a fifth definition of international education, one that views it as an export commodity. Galway (2000) describes the commodification of education as the process of turning education into an article of trade. She concluded that education is converted from a local initiative to educate the citizens of a nation, to one that is packaged and sold in other markets. In this definition, the focus is on the direct economic benefits to the institution and the country (CBIE, 1998).

Parmenter (2000) argues that internationalization can also be seen as an outward expression of self-interest, where the nation is still the dominant concept. She describes a process of looking out at the world from one's own native country and culture. This view of internationalization of education as a way of improving the country's national economic competitiveness is also put forward by Hamrick (1999), who looked at the development in light of the widely held perception that the countries of the Pacific Rim 
and a united Europe could challenge America's domination of the world's economy. Reports that American students were falling behind students from other developed nations in math and science, as well as knowledge of foreign languages and geography, only served to heighten these concerns.

\section{International Student Recruitment}

The literature dealing with the subject of the recruitment of international students covers several different aspects of the topic, ranging from a historical view that traces the evolution of this practice to one that examines the reasons institutions and governments participate in international student recruitment; why international students wish to study in countries like Canada, the United States, the United Kingdom, or Australia; and how these countries and educational systems compete for the lucrative international student market. The literature also provides some discussion of the concerns and controversy that exists with regard to many aspects of the recruitment of international students.

\section{International Student Recruitment by Community Colleges}

Prior to and during the 1960 s, American community colleges were only minimally involved in international education. According to O'Banion (1989), only a few colleges were involved in the recruitment of foreign students, the sending of students on "summer-abroad" study programs, and/or faculty exchanges with foreign institutions. Gleazer (1998) traces much of the leadership in the development of international student recruitment in the American community college sector to independent and church related junior colleges that were experiencing dramatic growth in the 1960s. O'Banion (1989) and Raby (2000) write that most of this activity through the 1970 s and 1980 s was driven by foundations (O'Banion mentions the W. K. Kellogg Foundation, the Ford Foundation, and the Johnson Foundation) or college consortiums like Community Colleges of International Development (CCID), and had as the focus, providing consultation services to foreign governments, 
organizations, and institutions; the provision of technical expertise and training; and the transfer of the necessary technology to enable foreign, largely developing, countries to achieve their goals of economic and educational development.

In Canada, a similar growth in international student enrolment was taking place in the college sector. Hurabielle (1998) found that between 1960 and 1970 only 10 percent of Canadian institutions reported having international students enrolled, while by 1986 this had grown to 82 percent. Galway (2000) reported that by the time of her study in the late 1990s, all 24 Colleges of Applied Arts and Technology in Ontario had international students enrolled on their campuses.

Initially, Canadian international education was rooted in liberal humanism and driven by humanitarian concerns (Hurabielle, 1998). In summarizing the early years, Hurabielle noted that Canada saw itself as being more advanced than the south so had both the desire and the justification to assist nations in need. This form of international assistance was not expected to yield sizable financial returns to the institutions involved. The activity was largely brokered through the Association of Canadian Community Colleges (ACCC) or the Canadian Bureau for International Education (CBIE), and funded by the Canadian Government through the Canadian International Development Agency (CIDA) and through individual college contacts with organizations like Rotary International (Galway, 2000).

While the "wandering scholar" has been a part of university education in the United Kingdom and Europe for centuries (Bruch \& Barty, 1998), the growth in international students coming to the U.K. for technical and language education and training has mirrored the global trend and the growth in Canada and the United States over the last 25 years. In Australia, aggressive recruitment of foreign students since the mid-1980s, and the initiation of the government policy of full-cost fees, has resulted in dramatic growth. Burn (2000) writes that in 1984 there were 15,000 international students studying in Australia, and that by 1998 this had grown to 75,000 . Burn found that international students now constitute 10 
percent of all university students nationally, and in many institutions that number is more than 20 percent.

As with Australia, the mid-1980s saw the shift in focus in Canada from "aid to trade," as international student recruitment and educational exports became commodities (Galway, 2000; Knight, 1997; Fisher \& Rubenson, 1997), and colleges moved from the less lucrative, and therefore less attractive CIDA funded projects, to the marketing of programs at full cost recovery rates to foreign elites.

\section{Why Recruit International Students?}

In her speech to the 1998 ACAATO Annual Conference, CIDA president, Huguette Labelle, urged college leaders not to lose sight of the importance of the humanitarian side of international educational activities, and made the case that there was a higher purpose, in that these programs were vital to improving economic and social conditions in the developing world.

The humanitarian motivation to recruit international students has declined, replaced by a motivation to boost revenue and export earnings (Currie \& Newson, 1998). Walker (1999), Knight (1997), and Burns (2000) all acknowledge this shift, as they write that international student recruitment not only has emerged as a means of internationalizing institutions, but with the far higher tuition fees charged, has provided an attractive means of coping with decreases in government funding over the past two decades. In fact, Galway (2000) reported that the generation of revenue for the college was far and away the most frequently reported motivation for the recruitment of international students in the CAATs.

The literature also suggests that international students are important for the quality and relevance of higher education, as their presence on campuses across the country is a key part of building a stronger international and intercultural dimension to teaching and research and a crucial global perspective to Canadian campuses (AUCC, 2002). The AUCC brief also acknowledged the significant economic benefits that international students 
bring to Canadian universities and local communities across the country, and added the dimension that these students "brand" Canada, as once they return to their countries of origin, foreign students become ambassadors for Canadian trade and political interests abroad. Hurabielle (1998) found that $89 \%$ of respondents indicated that international education was a good vehicle to promote the sale of Canadian goods and services abroad.

These various motivations are supported by Galway (2000) who reported that the top three rationales that institutions gave for participating in the recruitment of international students were: the opportunity to generate revenue, the opportunity to bring foreign perspectives to the local student body, and the opportunity to foster international trade links.

\section{The Competition for International Students}

With over 1.8 million international students worldwide (Bohm, Davis, Meares, \& Pearce, 2002), the competition for a share of that pool has become intense. In 1980, a full 40 percent of international students worldwide attended institutions in the United States, although this proportion dropped to 32 percent by 1998 .

Jacobson (2003) examines the state of international student recruitment in the United States in a post-9/11 world, and finds, not surprisingly, that while the total number of international students continues to grow, the number of foreign students coming to the U.S. in 2002/2003 was almost unchanged from the previous year. Growth rates of 6.4 percent in 2000/2001 and 2001/2002 had given way to a growth rate of less than one percent in 2002-2003. While there had continued to be increases from China, India, and South Korea, 25 percent fewer students came from Saudi Arabia and Kuwait, with significant decreases, as well, from other Muslim countries like Pakistan, Malaysia, and the United Arab Emirates. The article quotes the acting director of the Saudi Ministry of Higher Education as saying that they are looking to Canada, Australia, and New Zealand as alternatives to the United States, which is born out in statistics that show that the growth rate in students from countries bordering the Persian Gulf and studying 
in Australia has increased ten-fold from 1998 (slightly more than 100) to 2003 (more than 1000). It is also noted that the United Kingdom has enjoyed continued growth rates of between 12 and 15 percent per annum, with increased numbers of students from the Middle East over the last two or three years.

An AUCC background paper (2002) that examined the global competition for international students noted that many national governments have made significant investments in order to position their higher education sector competitively. They found that in Canada, federal support for key international scholarship and student exchange programs (a key tool for recruiting international students) ranks low when compared to the annual investments by several OECD countries on a per capita basis: Australia $\$ 9.07$, Japan $\$ 4.94$, United States $\$ 4.70$, Germany $\$ 3.02$, Netherlands $\$ 2.86$, and Canada $\$ 0.80$.

Immigration policy also plays a key role in the recruitment of international students. In a 2001 presentation to the House of Commons Standing Committee on Citizenship and Immigration Canada, the AUCC reported that Canada's main international competitors, the United States, the United Kingdom, Australia, New Zealand, and France, all had national strategies for international student recruitment and, consequently, the importance of this goal was reflected in the policies of their respective immigration departments.

In Australia, for example, the AUCC (2001) reports that international students are permitted to make application to become permanent residents following the completion of study and are encouraged by the immigration system to do so, as they receive additional "points" toward their application because they have graduated from an Australian educational institution. The AUCC research showed that in 1999, 50 percent of new immigrants to Australia in the "independent immigrant" category were former students.

By contrast, the AUCC (2001), with its mission to help build capacity in developing countries, rather than encourage "brain drain," urged the Canadian Government not to embark on immigration policies that would overtly target international students as potential immigrants, for fear that foreign governments would withdraw support for study abroad. 
While Galway (2000) reported that the Canadian Government was not allocating sufficient resources to the Education Officers at their embassies abroad to be able to compete with either the United States or Australia, and that many of the immigration regulations work against the recruitment efforts by institutions, in her review of the role of education in Canada's Foreign Policy, she praised then-International Trade Minister Sergio Marchi for his creation, in 1998, of the Education Marketing Advisory Board. She referred to the new commitment of the Canadian government to the international education services marketplace, through the establishment of the advisory board and websites promoting Canada's educational products, as quite remarkable.

\section{Areas of Concern in International Student Recruitment}

Altbach and Davis (1999), while noting the increase in the numbers of internationally mobile students, found that this trend was not without some serious consequences. They noted that as the job market for individuals with "transnational competencies" has grown, the opportunities for these individuals to move from developing countries to developed countries has also grown. They cite the transfer of talent from developing countries such as India and China to the developed world, giving the example of the United States, where 75 percent of the advanced international students from particular countries studying in engineering and the sciences, stay in the United States following graduation, rather than returning to their home countries. Hurabielle (1998) and Stromquist (2002) also noted this as a concern in their discussions, with a particular focus on the needs of the Third World for the skills and technological advancements that can only come through the development of an educated workforce. This is the "brain drain" concern raised in the previously mentioned brief by the AUCC (2001).

Knight (1997), Walker (1999), and Galway (2000) comment on another area of concern where trends in the commercialization of international student recruitment has a negative impact on the developing world. Galway 
in particular cites Ubadigbo (1997) who expresses grave concerns over "a dangerous trend" in international student enrolments in the United States, that being the targeting by university and college recruiters, of countries where there are students who can afford to pay high international student fees, and the ignoring of students from poor countries. Kenya (16th) is the only African nation that ranks in the list of the top 20 places of origin for foreign students in the U.S. in 2002/2003 (Jacobson 2003), and a similar list for the Ontario CAATs shows no African nations in the top 20 for 2001 (ACAATO, 2002).

Galway (2000) also found that misunderstandings about the impact on the presence of international students on the availability of seats in programs for local students existed at many colleges. One respondent disputed the perception that international students deprive local students of seats, and expressed the view that the funds raised from the recruitment of international students actually provided seats for local students and allowed the college to offer "great" programs.

There are also concerns about international student recruitment and issues around global human rights and the export of western culture and values (Galway, 2000; Hurabielle, 1998) and concerns that some Canadian institutions had been actively recruiting students from countries with terrible human rights records. When Galway asked about these practices, the various colleges gave examples of how they had avoided active participation in South Africa until the fall of apartheid, withdrew from China after the Tiananamen Square massacre, or refused to be involved with a program in Libya that involved teaching students how to make weapons. Further to this, Galway (2000) recorded very strong negative responses from the colleges she surveyed to a question about the role that international education plays in the "colonization" of developing nations through the transportation of western ideas and values. She concluded that while most of the respondents rejected the notion that the recruitment of international students or the offering of international programs served to colonize developing countries, most also stressed that they went to great lengths to ensure that their programs respected cultural values and needs. 


\section{International Student Recruitment in the CAATs}

There are a number of reasons why the CAATs consider themselves well positioned to be offering training and education to foreign students. For more than 37 years, Ontario colleges have demonstrated a strong track record in raising the educational and training level of the workforce in order to boost economic development and productivity (ACAATO, 2002). The colleges offer education and training in areas in which most foreign countries are interested. Galway (2000) found that, often, foreign purchasers were not interested in acquiring university education, but were looking for specific skills training. "The colleges can train the midlevel technicians and technologists that developing economies need, and can provide highly skilled training that may not be available elsewhere" (Galway, 2000, p. 6).

Galway (2000) reported that the majority of the colleges she surveyed (17 of 19) had established offices in order to coordinate international student recruitment and other international programs. Given the earlier reported revenue generation motivation for the majority of the international activity in the CAATs, it is not surprising to note that she found that most of these offices are expected to be self-funded from project revenue and/or international student tuition. She did, however, note the comments of college presidents to the effect that it is "nice" if the international office makes money, but they don't make a significant contribution to college budgets and that international education is more about faculty development and the enrichment of both the student body and the community.

Research into this matter undertaken for this article, which received responses from the international offices of several CAATs, revealed that colleges reported revenues that were in some cases as much as 10 times greater than the costs of staffing an international office and undertaking recruitment efforts in the international education marketplace. One International Coordinator gave the example of a recruitment trip to Jordan that cost $\$ 10,000$, but resulted in the recruitment of 10 students, and the generation of almost $\$ 90,000$ in tuition revenue for the college. 
For the current academic year, the Ontario College Application Services (OCAS) reported that, as of November 2003, there are a total of 158,028 full-time students enrolled in full-time post secondary programs across the CAATs, of which 5,856 (3.7 percent) are full-time international students. With tuition fees reported by the Committee of Registrars, Admissions, and Liaison Officers (CRALO) in their 2003 Ontario College Fee Survey, released November 28, 2003, ranging from $\$ 8,000$ CAD to $\$ 10,450$ (the standard tuition for Canadian residents and landed immigrants is $\$ 1,820$ ), this represents a total dollar value of $\$ 55.9$ million for the Ontario colleges. The attraction of recruiting international students becomes obvious when one considers that the 3.7 percent of the student population who are recruited internationally generate roughly 20 percent of the total tuition revenue raised by the resident and landed immigrant students in the province. Consider the potential financial impact on the CAATs in tuition alone, if the 10 percent level enrolments of international students enjoyed by Australian universities was replicated.

While all 24 colleges reported having international students, two of the northern colleges (Sault College and Northern College) only had one international student each. Seneca College in Toronto, which is the largest of the CAATs with a total enrolment of almost 16,000 students, had both the largest number of international students $(1,551)$ and the greatest percentage enrolment of international students at 9.7 percent. Three other Toronto colleges-George Brown College, Centennial College, and Humber College-followed in numbers of students with 892 students (7.8 percent of enrolment), 584 students ( 5.7 percent of enrolment), and 570 students (4.1 percent of enrolment), respectively. Mohawk College in Hamilton rounded out the top five, with 394 international students or 6.7 percent of total enrolment. Given the "multicultural majority" that exists today in Toronto, and the broad ethnic and cultural diversity in the surrounding urban area, it is probably no surprise that the colleges in this area attract the largest numbers of international students. There are strong local communities from almost all national groups able to 
Table 1

Top-Twenty Countries for Students attending Ontario Colleges in 2000-2001

\begin{tabular}{lcc}
\hline \multicolumn{1}{c}{ Country } & Rank & $\begin{array}{c}\text { Student } \\
\text { Authorization Issued }\end{array}$ \\
\hline South Korea & 1 & 11,464 \\
China & 2 & 7,808 \\
Japan & 3 & 6,522 \\
Mexico & 4 & 4,473 \\
France & 5 & 4,373 \\
Taiwan & 6 & 2,673 \\
Germany & 7 & 1,989 \\
Hong Kong & 8 & 1,880 \\
Brazil & 9 & 1,866 \\
Columbia & 10 & 986 \\
England & 11 & 950 \\
India & 12 & 923 \\
United States & 13 & 801 \\
Switzerland & 14 & 658 \\
Venezuela & 15 & 652 \\
Turkey & 16 & 535 \\
Australia & 17 & 525 \\
Indonesia & 18 & 487 \\
Thailand & 19 & 471 \\
Sweden & 20 & 431 \\
& & \\
\hline & & \\
\hline
\end{tabular}

Source: CAIPS offices - Produced by Operation Coordination (RIM) on Jan. 30, 2001, Citizenship and Immigration Canada. 
provide support and links to home for international students. By contrast, Dietze (2003) found that the smaller, rural CAATs faced challenges in international student recruitment due to the limited multicultural nature of their communities, students, and staff.

The majority of international students in the CAATs today originate from Asia. A review of data from the Association of Colleges of Applied Arts and Technology of Ontario's Environmental Scan for 2001 that listed the top-twenty countries of origin for students attending Ontario colleges (ACAATO, 2002), revealed that the top three Asian countries (South Korean, China, and Japan) accounted for more students than the remaining 17 countries combined (which also included Taiwan and Hong Kong).

\section{CONCLUSION}

With the increased pressures of globalization, through the ongoing development of the GATS, the commodification of higher education, and the dramatic increases in the global demand for international higher education, there can be no doubt that the internationalization of the CAATs, as largely manifested in the growth in international student enrolments, will continue to be of great importance to both the institutions involved and to the provincial and federal governments.

The CAATs have already felt the financial impact of the proliferation of private-for-profit colleges, which have competed aggressively for training contracts and students across the province. If, as some have predicted, the GATS results in open competition from larger international education and training providers, particularly those from the United States, the CAATs and the rest of the Canadian education sector must prepare themselves not only to compete on their home turf, but for a place in the global marketplace (Ontario Ministry of Training, Colleges, and Universities, 2002).

Ontario and Canada have a well-deserved reputation for safety, tolerance, and the strong support for multiculturalism that make it a desirable destination for international students. The CAATs have a well- 
established history of providing quality education and training that has supported the development of almost all sectors of the economy in Ontario, across Canada, and increasingly, around the world. To succeed, the CAATs and the education systems across the country must market these two realities more effectively. Researchers, educators, and governments can learn much from an examination of the success in international student recruitment efforts of our major competitors: Australia, the United States, New Zealand, and the United Kingdom. It is vitally important that further studies be undertaken to help position Ontario, Canada, and the CAATs in the global marketplace.

As the number of international students seeking educational opportunities grows to over 7 million over the next 20 years, the ability of the CAATs, the Canadian educational system, and the governments of Ontario and Canada to market the Canadian experience, and the educational opportunities available in the CAATs to potential international students will, in great measure, determine their success and their survival in an increasingly globalized world. 


\section{References}

Altbach, P., \& Davis, T., (1999). Global challenge and national response: Notes for an international dialogue on higher education, Chapter 1, pp. 3-10. Higher Education in the 21st Century: Global Challenge and National Response, IIE Research Report No. 29. The Institute of International Education.

Association of Colleges of Applied Arts and Technology of Ontario. (2000). Environmental Scan 2000. Retrieved September 24, 2003, from the World Wide Web.

Association of Colleges of Applied Arts and Technology of Ontario. (2002). Environmental Scan 2002. Retrieved September 24, 2003, from the World Wide Web.

Association of Colleges of Applied Arts and Technology of Ontario. (2002). The competitive colleges platform: The urgent need for strategic investment. Toronto: ACAATO.

Association of Colleges of Applied Arts and Technology of Ontario. (December, 2002). Research news. Toronto: ACAATO.

Association of Universities and Colleges of Canada. (February, 2001). Canadian higher education and the GATS. AUCC Background Paper.

Association of Universities and Colleges of Canada. (March, 2001). Recognizing the importance of international students to Canada in the Immigration and Refugee Protection Act. A brief submitted to the House of Commons Standing Committee on Citizenship and Immigration Canada.

Association of Universities and Colleges of Canada. (February, 2002). Making Canada more attractive to international students. A brief submitted to the House of Commons Standing Committee on Citizenship and Immigration Canada.

Association of Universities and Colleges of Canada. (2002). International student recruitment. AUCC Background Paper.

Association of Universities and Colleges of Canada. (May, 2003). Canadian excellence in and for the world: How the globalization of higher education and research contributes to Canada's Foreign Policy. A brief submitted to Dialogue on Canadian Foreign Policy, Department of Foreign Affairs and International Trade.

Birchard, K. (2003, June 24). Ontario's community colleges fault government for insufficient support. Chronicle of Higher Education. Retrieved May 11, 2003 from the World Wide Web. 
Blair, D., Phinney, L., \& Phillippe, K.A. (2001). International programs at community colleges. American Association of Community Colleges: Research Brief. AACC-RB-01-1.

Bohn, A., Davis, D., Meares, D., \& Pearce, D. (2002). Global student mobility 2025: Forecasts of the global demand for international higher education. Sydney: IDP Education Australia.

Bruch, T., \& Barty, A. (1998). Internationalizing British higher education: Students and institutions. In P. Scott (Ed.). (1998), The globalization of higher education. Philadelphia, PA: The Society for Research into Higher Education.

Burn, B. (Winter, 2000). Australia and foreign student recruitment. International Higher Education. Boston: Centre for International Higher Education, Boston College.

Canadian Bureau for International Education. (1998). Annual report: Education without borders or bounds. Ottawa: CBIE.

Canadian Federation of Students. (2001). How the GATS threatens post-secondary education. Fact Sheet 2001, Vol. 7, No. 4.

Committee of Registrars, Admissions, and Liaison Officers (CRALO) - Ontario CAATS. (November, 2003). Ontario college fee survey. Published via email.

Currie, J. (1998). Globalization as an analytical concept and local policy response. Universities and globalization: Critical perspectives. Thousand Oaks: Sage Publications, Inc.

Currie, J., \& Newson, J. (Eds.). (1998). Universities and globalization: Critical perspectives. Thousand Oaks: Sage Publications, Inc.

Dennison, J., \& Gallagher, P. (1986). Canada's community colleges: A critical analysis. Vancouver: The University of British Columbia Press.

Dietze. B. (2003). Globalizing the curriculum: The beginning of a new educational learning culture and learning community. Unpublished paper. Belleville, $\mathrm{ON}$ : Loyalist College of Applied Arts and Technology.

Dudley, J. (1998). Globalization and educational policy in Australia. Universities and globalization: Critical perspectives. Thousand Oaks: Sage Publications, Inc.

Fisher, D., \& Rubenson, K. (1998). The changing political economy: The private and public lives of Canadian universities. Universities and globalization: Critical perspectives. Thousand Oaks: Sage Publications, Inc. 
Galway, A.D. (2000). Going global: Ontario Colleges of Applied Arts and Technology, international student recruitment and the export of education. Toronto, ON: Ontario Institute for Studies in Education, University of Toronto.

Hamrick, J. (1999). Internationalizing higher educational institutions: Broadening the approach to institutional change. Paper presented to the Managing Institutional Change and Transformation Project, University of Michigan. Retrieved August 23, 2002, from the World Wide Web.

Hurabielle, J. (1998). Canada's public colleges and postsecondary technical institutions involvement in international education. Ph. D. Thesis, University of Alberta.

International Journal of Engineering Education. (1998). Engineering Education World, Vol. 14, No. 3, Tempus Publications.

Jacobson, J. (November, 2003). Foreign-student enrollment stagnates, new security measures lead to declines among Muslim countries. Chronicle of Higher Education.

Knight, J. (1994). Internationalizing higher education: A shared vision. A project report in the perspectives of the private, government and education sectors on the internationalization of higher education in Canada. Association of Universities and Colleges of Canada.

Knight, J. (1997). A shared vision? Stakeholders' perspectives on the internationalization of higher education in Canada. Journal of Studies on International Education, Vol. 44, No 1, pp. 27-31.

Labelle, H. (1998). Meeting the challenges of the 21st century: Canadian community colleges in a global village. Sisco Address at the Annual Conference of the Association of Colleges of Applied Arts and Technology of Ontario, Ottawa, ON.

Maccan, R. (Summer, 2003). Canada's scattered approach to international education. Internationaliste, Vol. 14, No. 2, pp. 10-11, Canadian Bureau for International Education.

McGill Peterson, P. (April, 2002). Addressing the challenge to internationalize our academic institutions: How are we doing? An address to the American Council on International Intercultural Education Conference. Seattle, Washington.

O'Banion, T. (1989). Innovation in the community college. New York: American Council on Education, Macmillan Publishing Company.

Ontario Ministry of Colleges and Universities Act. (1980). Sections 1-8 (Governance of CAATs-sections 5-8). R.S.O. 
Ontario Ministry of Training, Colleges, and Universities. (2002). Ontario's colleges for the 21st century: Capacity and charter framework.

Ostry, S. (March, 1999). Globalization and sovereignty. James R. Mallory Annual Lecture in Canadian Studies. Montreal: McGill Institute for the Studies of Canada.

Raby, R. (2000). Globalization of the community college model: Paradox of the local and the global. In N.P. Stromquist \& K. Monkman. (2000). (Eds.), Globalization and education: Integration and contestation across cultures. Lanthan, Maryland: Rowman \& Littlefield Publishers, Inc.

Rikowski, G. (January, 2002). Globalization and education. A paper presented to the House of Lords Select Committee in Economic Affairs - Inquiry into the Global Economy. London.

Scott P. (Ed.). (1998). The Globalization of higher education. Philadelphia, PA: The Society for Research into Higher Education.

Stromquist, N.P. (2002). Education in a globalized world: The connectivity of economic power, technology and knowledge. Lanthan, Maryland: Rowman \& Littlefield Publishers, Inc.

Stromquist, N.P., \& Monkman, K. (Eds.). (2000). Globalization and education: Integration and contestation across cultures. Lanthan, Maryland: Rowman \& Littlefield Publishers, Inc.

Stromquist, N.P., \& Monkman, K. (2000). Defining globalization and assessing its implications on knowledge and education. In N.P. Stromquist \& K. Monkman (Eds.), Globalization and education: Integration and contestation across cultures. Lanthan, Maryland: Rowman \& Littlefield Publishers, Inc.

Walker, P. (1999). Buying in and selling out-quality issues in international student contracting arrangements. Quality in Higher Education, Vol. 5, No. 3.

Walsh, D.C. (November, 1998). Internationalizing education: Laying the foundation for global citizenship. An address to the Council on International Education Exchange, Annual Meeting, Boston, MA.

Zeszotarski, P. (Summer, 2001). Eric Review: Issues in global education initiatives in the community college. Community College Review, Vol. 29, No. 1. 